\title{
EXPERIMENTAL STUDY OF CHLORIDE TRANSPORT INTO DOUBLE LAYERED COMPONENTS WITH CONCRETE AND RENDERING MORTAR
}

\section{ESTUDIO EXPERIMENTAL DE LA PENETRACIÓN DE CLORURO EN COMPONENTES CON DOBLE CAPA DE HORMIGÓN Y MORTERO DE RECUBRIMIENTO}

Raphaele Malheiro (Main author)

Minho University Guimarães. Civil Engineering Department, Portugal.

raphamalheiro@gmail.com

Gibson Rocha Meira (Contact author)

Federal University of Paraíba. Civil and Environmental Engineering Postgraduate Programme, Brazil.

Federal Institute of Education, Science and Technology. Civil Engineering Department, Paraíba, Brazil.

R. Dep. Balduíno M. de Carvalho, 155/1104, 58.036-860 João Pessoa, Brazil

gibson.meira@ifpb.edu.br

\section{Munique Lima}

Federal Institute of Education, Science and Technology. Civil Engineering Department, Mato Grosso do Sul, Brazil. munique.lima@ifms.edu.br

Manuscript Code: 647

Date of Acceptance/Reception: 10-5-2016/09-06-2015

\begin{abstract}
This work studied the influence of rendering mortar layer on chloride transport into concrete structures. Concrete specimens rendered with three different mortar mixtures and two rendering thickness were used. Five of the six faces of the specimens were coated with epoxy resin to simulate unidirectional flux. The specimens were subjected to weekly wetting and drying cycles in a sodium chloride solution for 49 days. At the end, total chloride profiles were obtained. Results show that rendering mortars influence chloride transport into concrete and this is more accentuated for less porous mortars and with higher cement content. There is also a chloride accumulation close to the interface mortar-concrete region, which is explained by the differences on chloride transport ability between mortar and concrete. Although mortars are more porous than concrete, they can represent an additional protection against chloride penetration into concrete.
\end{abstract}

Keywords: Concrete, mortar, rendering, chloride, protection.

\section{Resumen}

Este trabajo estudió la influencia de la capa de mortero en el transporte de cloruros en estructuras de hormigón. Probetas de hormigón con capas de tres distintos morteros y dos espesores de revestimiento fueron empleadas. Las probetas tuvieron cinco de sus seis caras pintadas con resina epoxi para simular un flujo unidireccional y fueron sometidas a ciclos semanales de inmersión y secado en disolución de cloruro sódico a lo largo de cuarenta y nueve días. Al final, perfiles de cloruro totales fueron obtenidos. Los resultados indican que la capa de mortero influye en el transporte de cloruro en el hormigón y esta influencia es más fuerte en el caso de los morteros menos porosos y más ricos en cemento. También se observa una acumulación de cloruro cerca de la interface mortero-hormigón, la cual es explicada por las diferencias en la capacidad de transporte entre mortero y hormigón. A pesar de que los morteros son más porosos que el hormigón, estos pueden representar una protección adicional respecto a la penetración de cloruro en el hormigón.

Palabras clave: Hormigón, mortero, recubrimiento, cloruro, protección.

Introduction

The early deterioration of reinforced concrete structures in coastal areas has been an important problem over the past decades. The action of the chloride ions, as a triggering agent for the reinforcement corrosion, is certainly one of the most important causes of deterioration of concrete structures in marine environment (Aiticin, 2000). These ions penetrate into bulk concrete mainly through two mechanisms: capillary absorption and diffusion (Kröpp, Hilsdorf, Grube, Andrade \& Nilsson, 1995; Nilsson and Tang, 1996). The corrosion process starts when the ions reach the reinforcement surface in sufficient amounts (Glass and Buenfeld, 1997; Castro, De Rincon \& Pazini, 2001). This mass transport takes place when the concrete surface or overlapping layers have contact with seawater or, in most cases, contact with marine aerosol (Meira, Andrade, Alonso \& Borba, 2007a; Meira, Andrade, Padaratz, Alonso \& Borba, 2007b; Lindvall, 2007).

Studies on the influence of the material characteristics in the chloride transport into concrete show the role of aspects such as the porous structure of materials (Tuutti, 1982; Jaegermann, 1990; Mangat and Molloy, 1994), the presence of 
cracks (Mangat and Gurusamy, 1987; Bakker, 1988) and chloride binding ability of the cementitious matrix (Byfors, 1990; Rasheeduzzafar, Al-Saadoun, Al-Gahtani, and Dakhil, 1990) on accelerating or delaying chloride transport into concrete. Papers on the influence of environmental characteristics represent another group of studies, covering aspects such as temperature (Page, Short, \& El Tarras, 1981; Al-Khaja, 1997), concrete carbonation (Byfors, 1990; Jones, McCarthy, and Dhir, 1994; Malheiro, 2015), location of structures (Vera et al., 2009) and saturation degree of concrete porous network (Climent, de Vera, López, Viqueira, \& Andrade, 2002; Nielsen and Geiker, 2003; Guimarães and Helene, 2005; de Vera, Climent, Viqueira, Antón, \& Andrade, 2007; Guimarães et al., 2011).

Many studies consider concrete or mortar independently, not as double layered systems with distinct materials. However, most buildings built on Brazilian coastal areas have the concrete structures coated and the mortar layer representing an initial barrier that the chloride ions need to cross before reaching the concrete. For single layered systems, the mass transport by diffusion is well represented by Fick's 2nd law (Crank, 1975), which solution is represented by the equation (1), where $\mathrm{Cs}$ is the surface chloride concentration, $\mathrm{C}$ is the inner chloride concentration, $D$ is the diffusion coefficient, $x$ is the depth and $t$ is the exposure time. This solution is based on constants Cs and $D$, which is an approximation to real conditions. However, this simplified model is still used for analysing chloride transport into concrete.

$$
C(x, t)=C_{s}\left[1-\operatorname{erf}\left(\frac{x}{2 \sqrt{D . t}}\right)\right]
$$

Concerning double-layered systems, Crank (1975) presented a mathematical approach on mass transport by diffusion. Taking into account the skin effect, Andrade, Díez and Alonso (1997b) proposed Eqs. (2) - (4) as a solution for the chloride transport by diffusion in materials with different transport characteristics between the surface and bulk. In these equations, $\mathrm{C} 1$ is the chloride concentration in the external layer, $\mathrm{C} 2$ is the chloride concentration in the internal layer, D1 is the diffusion coefficient in the external layer, D2 is the diffusion coefficient in the internal layer, Cs is the surface chloride concentration, e represents the thickness of the external layer (skin), R corresponds to the resistance, if any, between the two layers (external and internal), $\mathrm{x}$ is the depth studied and $\mathrm{t}$ is the exposure time demanded in the study (Figure 1).

$$
\begin{aligned}
& C_{1}(x, t)=C_{s} \sum_{n=0}^{\infty} \alpha^{n}\left(\operatorname{erfc}\left[\frac{2 n e+x}{2 \sqrt{D_{1} t}}\right]-\alpha \operatorname{erfc}\left[\frac{(2 n+2) e-x}{2 \sqrt{D_{1} t}}\right]\right) \\
& C_{2}(x, t)=\frac{2 k C_{s} R}{k+1} \sum_{n=0}^{\infty} \alpha^{n} \operatorname{erfc}\left[\frac{(2 n+1) e+k(x-e)}{2 \sqrt{D_{1} t}}\right] \\
& k=\sqrt{\frac{D_{1} / D_{2}}{2}} \quad \alpha=1-k / 1+k ; \quad C_{1}(e, t)=R C_{2}(e, t)
\end{aligned}
$$

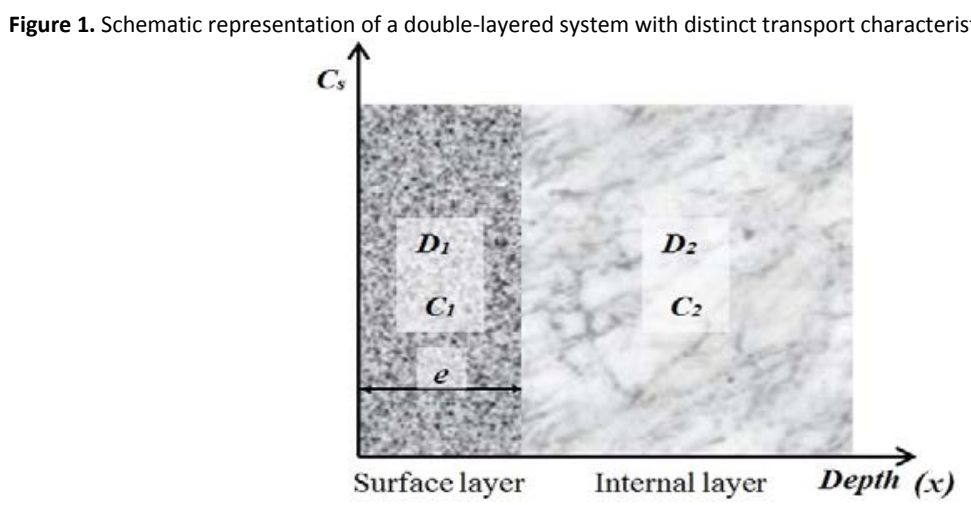


Although this approach has also some limitations, such as not taking into account the time dependence of the chloride diffusion coefficient or the non-linearity of binding capacity of cement-based materials, it can provide useful information for the case of double-layered systems without the requirement of many input parameters, which may represent a barrier to more sophisticated models (Martín-Perez, 1999; Meijers, 2003).

The majority of studies on chloride transport in double-layered systems are simulations. There is a lack of experimental studies. One contribution in the experimental field was performed by Kreijger (1984) by identifying the formation of a more porous surface layer with transport characteristics differentiated from the bulk material, which characterizes the skin effect (Andrade, Díez and Alonso, 1997a; Andrade et al., 1997b). Although numerous studies take into account the durability performance of concrete and mortar individually, less has been done regarding the combined behaviour of these materials as a double-layered system.

This work presents an experimental study on the influence of chloride transport in rendering mortars on chloride penetration into coated concrete structures (double-layered systems), simulating field conditions of application of these materials.

Experimental work

\section{Materials}

The aggregates used in this study were natural quartz sand with $2.2 \mathrm{~mm}$ fineness modulus and maximum diameter of $4.8 \mathrm{~mm}$, and crushed granite with maximum diameter of $9.5 \mathrm{~mm}$ as coarse aggregate. The water used came from the public water supply system with chloride content of about $1 \mathrm{mg} / \mathrm{l}$. The cement type used was a Brazilian Portland Cement with high early strength (ASTM type III), whose physicochemical characteristics are shown in Table 1 . The hydrated lime selected for this work was a Brazilian one, normally used in the studied region, whose characteristics are also presented in Table 1.

\begin{tabular}{|c|c|c|c|}
\hline Composition/property & 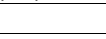 & Portland cement & Hydrated lime \\
\hline $\mathrm{SiO} 2(\%)$ & & 20.06 & 0.44 \\
\hline Al2O3 (\%) & & 5.99 & - \\
\hline Fe2O3 (\%) & & 2.18 & 0.08 \\
\hline $\mathrm{CaO}(\%)$ & & 60.48 & 67.76 \\
\hline $\mathrm{MgO}(\%)$ & & 3.82 & 2.82 \\
\hline $\mathrm{Na} 2 \mathrm{O}(\%)$ & & 0.94 & 0.18 \\
\hline $\mathrm{K} 2 \mathrm{O}(\%)$ & & 1.09 & 0.05 \\
\hline Insoluble residue - IR (\%) & & 0.46 & 0.12 \\
\hline Loss on ignition - LI (\%) & & 2.65 & 27.49 \\
\hline \multirow[t]{4}{*}{ Potential composition (Bogue equations) } & C2S (\%) & 19.49 & - \\
\hline & C3S (\%) & 50.40 & - \\
\hline & C3A (\%) & 12.18 & - \\
\hline & C4AF (\%) & 6.63 & - \\
\hline Blaine $\left(\mathrm{cm}^{2} / \mathrm{g}\right)$ & & 4815 & - \\
\hline Specific density $\left(\mathrm{g} / \mathrm{cm}^{3}\right)$ & & 3.09 & 2.42 \\
\hline Compressive strength -28 days ( $\mathrm{MPa}$ ) & & 34.94 & - \\
\hline
\end{tabular}

\section{Specimens casting}

The specimens used in this work were made in two stages: casting concrete substrate and execution of the rendering layer, following procedures usually adopted in construction sites and whose details are presented in the next paragraphs. Reference specimens were also cast only in concrete to promote comparisons with layered specimens. Initially, concrete cubes were cast in the dimensions $8 \times 8 \times 8 \mathrm{~cm}$, whose mixture details are presented in Table 2 . The water to cement ratio used was 0.55 . Slump, compressive strength, water absorption and capillary absorption tests were performed for concrete characterization. All hardened concrete tests were performed at 28 days (Table 2 ).

The water absorption and capillary absorption tests were made according to Brazilian standards NBR 9778 (ANBT, 1987) and NBR 9779 (ANBT, 1995), respectively. For these tests, the preconditioning consists in drying the samples in 
a chamber under $105 \pm 5$ 으. For water absorption test, the samples remained in the chamber during 72 hours. For capillary absorption test, the samples remained there until reaching constant mass.

After being removed from the moulds, the concrete substrates remained in laboratory environment until reaching the age of 120 days. This condition was also applied to the reference specimens and tried to simulate the delay that usually occurs in the real building process between casting concrete elements and the execution of rendering layers. During this period, the specimens remained wrapped with plastic film to avoid materials carbonation.

\begin{tabular}{lllll}
\multicolumn{5}{c}{ Table 2. Concrete and mortar mixtures and properties. Source: Self-elaboration. } \\
\hline Material & Concrete & Mortar 1:3* & Mortar 1:1:6* & Mortar 1:2:9* \\
\hline Relative proportions (mass) / properties & & & & \\
\hline Cement & 1 & 1 & 1 & 1 \\
Hydrated lime & - & - & 0.30 & 0.59 \\
Sand & 2.52 & 3.53 & 7.05 & 10.58 \\
Coarse aggregate & 2.41 & - & - & - \\
Water to binder ratio & 0.55 & 0.6 & 0.83 & 1.11 \\
Cement (kg/m3) & 370 & 437 & 250 & 173.5 \\
\hline Air content - fresh mortar (\%) & - & 2 & 2 & 4 \\
Consistency level - Slump (mm) & $70 \pm 10$ & 262 & 264 & 262 \\
\hline Compressive strength (MPa) - 28 days & 30.43 & 23.59 & 11.82 & 5.65 \\
Capillary absorption (g/cm2) & 1.43 & - & - & - \\
Water absorption after immersion (\%) & 4.86 & 8.24 & 10.40 & 11.33 \\
Dry specific density (g/cm3) & 2.25 & 2.21 & 2.13 & 2.09 \\
Total porosity (\%) & 10.95 & 18.19 & 22.13 & 23.72 \\
\hline \multicolumn{5}{c}{ * Mortar mixture identification in volume. } \\
\end{tabular}

Afterwards, the concrete substrates had one of their faces cleaned by manual brushing and received a thin layer of bonding spatter dash treatment. For the bonding spatter preparation, a mortar mixture 1:3 (cement: sand, in volume) was used, as it is the most commonly used in building construction in the studied region (Malheiro, 2008), and it was manually applied with a trowel, similarly to the practice of construction sites. This procedure had the aid of a finemesh sieve in order to produce a thinner and more uniform bonding spatter.

After 3 days at rest, the rendering mortar was applied on the same face with $2.5 \mathrm{~cm}$ or $4 \mathrm{~cm}$ thickness. As a result, three types of test specimen were obtained (Figure 2). The rendering layers were done with mortar in three different mixtures: 1:3, 1:1:6 and 1:2:9 (cement: sand and cement: lime: sand - in volume). Mixtures and properties of mortars used are shown in Table 2.

Figure 2. Types of specimens used in the study with rendering mortar thicknesses of $40 \mathrm{~mm}$ and $25 \mathrm{~mm}$ and without rendering (reference specimens). Source: Self-

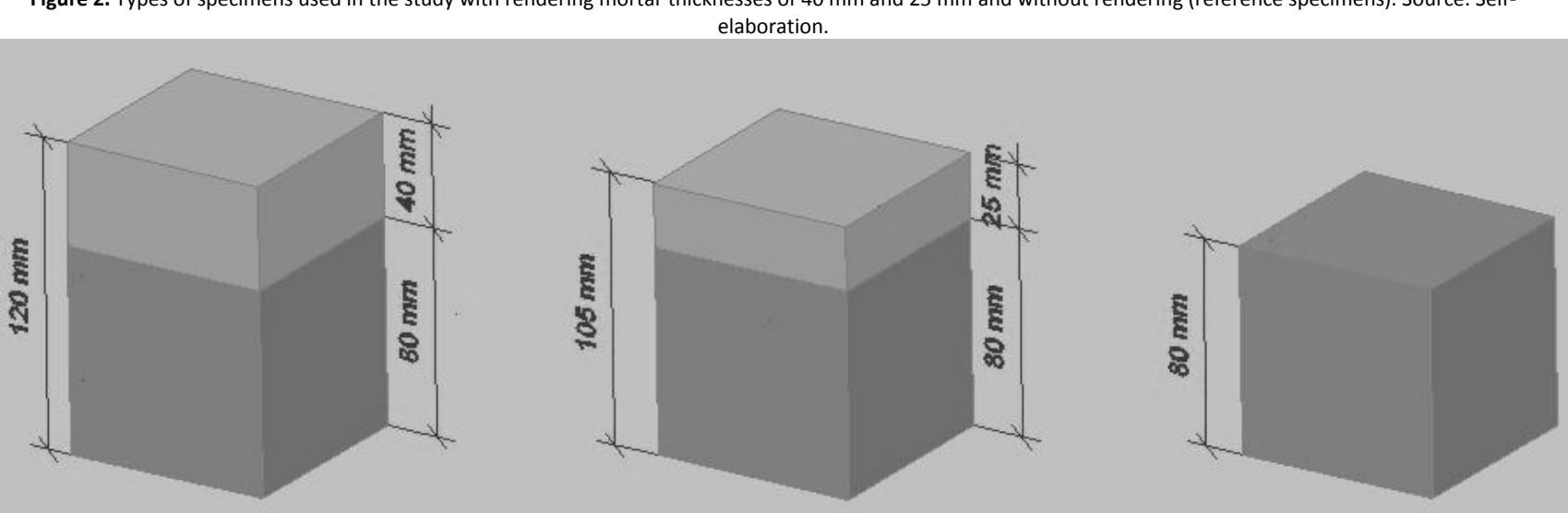

The thickness and mixtures chosen in this research for rendering mortars were based on a previous research carried out in João Pessoa city, Paraíba - Brazil, detailed in Malheiro (2008). These choices represent the high diversity of mortar mixtures and thicknesses used in the studied region. It is worth mentioning that a mortar rendering of $4 \mathrm{~cm}$ thickness should not be recommended, although it was usually observed in the field research (Malheiro, 2008). For this reason and taking into account the study on the influence of the mortar thickness variable, it was also decided to analyse the $4 \mathrm{~cm}$ thickness. 
Three specimens were used for each experimental condition. All of them had five of their six faces painted with epoxy resin 28 days after the execution of the rendering mortar layer (period in which they were also protected with plastic film to avoid carbonation). A single free face was used for the penetration of chloride ions into concrete with the objective of simulating a unidirectional flux. The main steps in preparing the layered specimens are summarized in Figure 3.

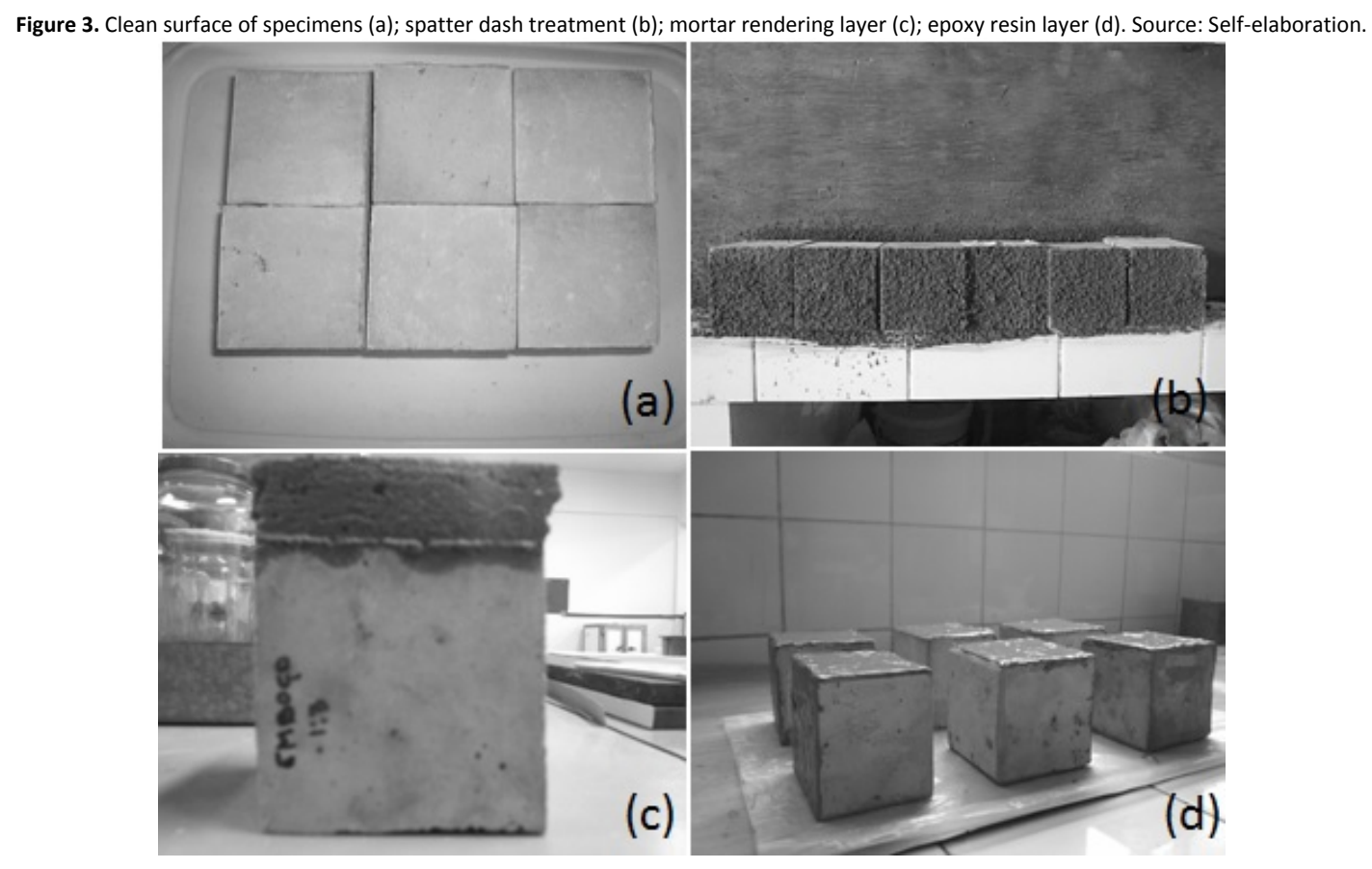

\section{Accelerated tests, samples extraction and chemical analysis}

After the steps described in section 2.2, the specimens were subjected to wetting and drying cycles in a one molar sodium chloride solution $(5.84 \% \mathrm{NaCl})$. The immersion occurred over three days and drying over four days in a laboratory environment $\left(\mathrm{RH}=68 \pm 5 \%, \mathrm{~T}=26 \pm 3{ }^{\circ} \mathrm{C}\right)$. These cycles were repeated for seven weeks. The number of cycles was chosen in order to harmonize the time of chlorides penetration into concrete and mortar, since these materials have significant differences on transport characteristics, as observed in preliminary tests performed with different exposure times. Fewer cycles could not be enough to clearly observe chloride ingress into concrete. On the other hand, more cycles could difficult comparative analysis among studied mortars due to a significant chloride accumulation in this region. The reference specimens were subjected to the same conditions imposed to the layered specimens. During these accelerated tests, the used containers remained closed in order to prevent partial evaporation of the solution and a consequent change of its concentration.

When the exposure period was over, the samples were marked according to the desired depth and were powdered at every $5 \mathrm{~mm}$ from surface to bulk. Close to the interface between mortar and concrete, the thickness was reduced to $2.5 \mathrm{~mm}$ in order to improve chloride profiles resolution in this region. Figure 4 shows schematically the distribution of the samples extracted from the studied specimens. The extraction of these samples was made through a dry process to prevent chloride removal by washing and employed a cutting/grinding apparatus with a diamond-based disc. 
Figure 4. Scheme of samples distribution: Layered specimens with $4.0 \mathrm{~cm}$ of rendering mortar thickness (a); layered specimens with $2.5 \mathrm{~cm}$ of rendering mortar thickness (b); reference concrete specimens (c). Source: Self-elaboration.

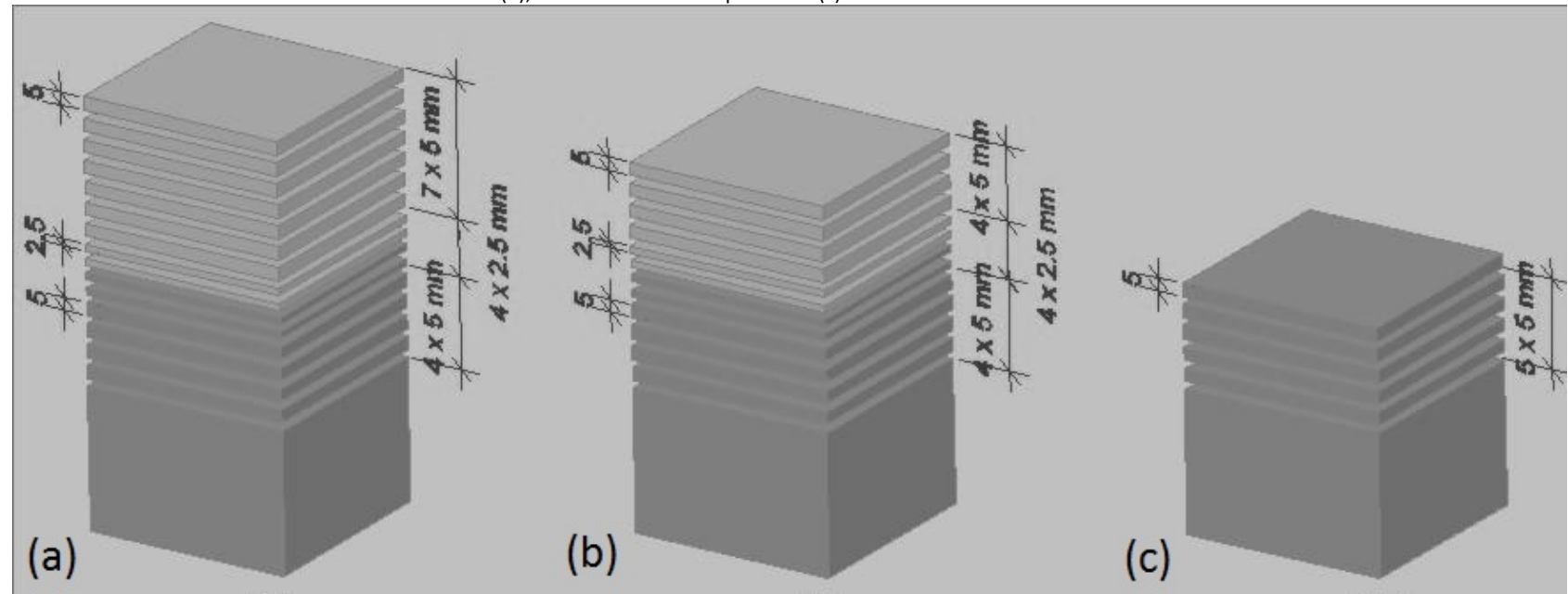

The powdered samples were prepared following the procedures described by the International union of laboratories and experts in construction materials, systems and structures - Andrade \& Castellote (2002) and total chloride contents were analysed by a potentiometric titration method, following similar procedures as described in ASTM C114 (1992).

Chloride profiles obtained from the experimental work are presented in Figures 5 and 6 for layered specimens. Taking into account the differences in materials composition, the percentage of sample mass was chosen to represent the results instead of the percentage of cement mass. The depicted points represent the average and standard deviations values for each depth analysed.

Figure 5 shows that there is a trend towards chloride content increase as mortar porosity increases and it also reveals that there is a formation of soft peaks in the region close to the mortar surface. These peaks, when well defined, are typical of the skin effect (Andrade and Alonso, 1995). Considering that this formation corresponds only to a trend which is not repeated for all profiles, and that the internal shape of the profiles resembles the typical diffusion profiles, it is likely that the diffusive transport has prevailed. This behaviour is justified by the short time for drying semi-cycles, associated with high relative humidity observed in the laboratory environment (typical for the region), which results in more superficial moisture exchange between the materials and the environment.

Figure 5. Chloride profiles for specimens with $2.5 \mathrm{~cm}$ of rendering mortar thickness. Source: Self-elaboration.

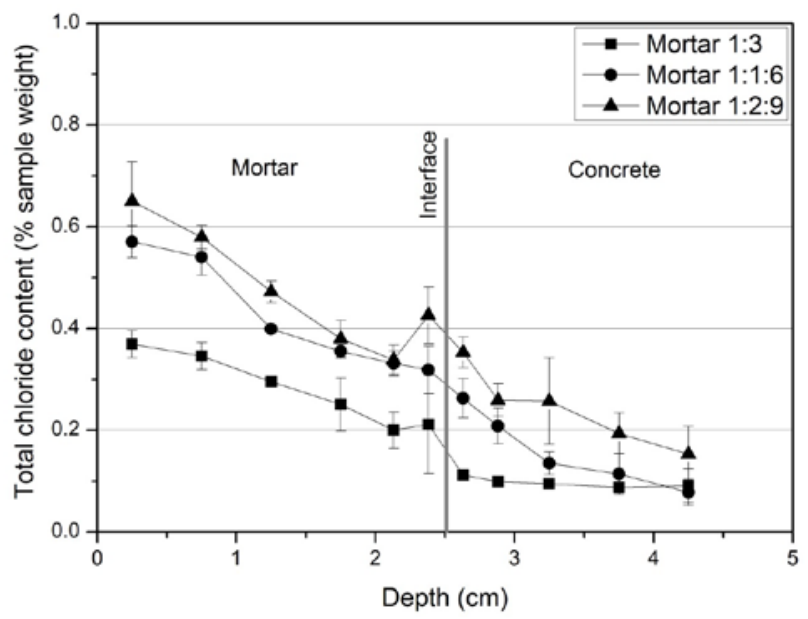

Figure 6. Chloride profiles for specimens with $4.0 \mathrm{~cm}$ of rendering mortar thickness. Source: Self-elaboration.

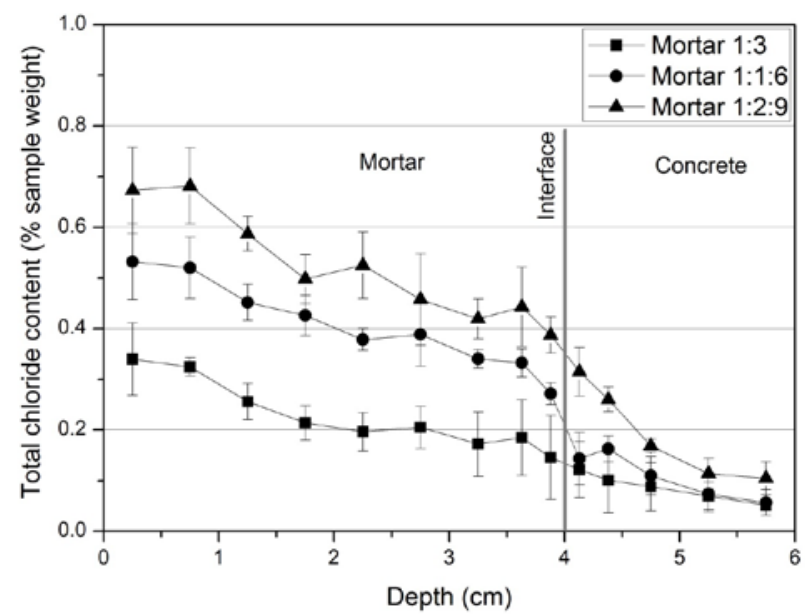


An accumulation of chlorides can also be observed in the region before the interface between mortar and concrete. This accumulation is followed by a significant drop in chloride concentration in the concrete area immediately after the interface. This behaviour shows that there is a resistance to chloride transport from the mortar region to the concrete region of the mortar, which is a consequence of differences on mass transport ability between mortar and concrete (Andrade, Díez and Alonso, 1997a).

Similar behaviour is also observed in Figure 6. However, lower chloride concentrations are observed in concrete layer due to the thicker rendering layer. This can be clearly seen in specimens with less porous mortars. Taking Figures 5 and 6 in comparison with the profile shown in Figure 7, which refers to the reference specimen (without rendering layer), significantly higher chloride concentrations can be observed in the last case, with values in the superficial layers of concrete that are more than two times higher than those for layered systems with mortar 1:3. This helps to demonstrate that the rendering layer may play a complementary role in protecting concrete structures against chloride penetration, as it is discussed in section 4.

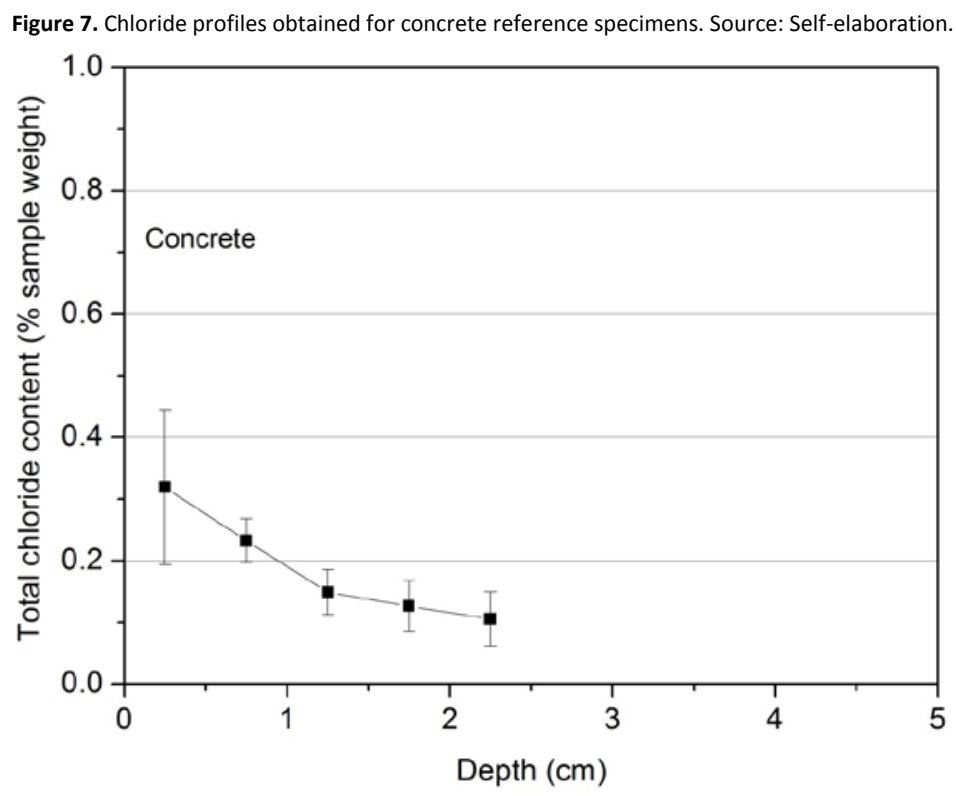

This section discusses the influence of material characteristics and the thickness of rendering layer on chloride transport in layered systems and also the resistance effect between mortar and concrete layers. It is important to point out that the analyses carried out in this section are based in short-term tests in laboratory environment. Although field aspects were respected in specimens production, there is a better control of experimental steps and the environmental degradation of rendering layer over time does not take place in laboratory. This way, the aspects discussed in this section may be considered under these limitations.

\section{Influence of material characteristics}

Chloride profiles presented in Figures 5 and 6 show that the studied mortars presented differences in their behaviour related to chloride penetration. Lower chloride contents can be observed in the mortar region when the mortar is less porous and richer in cement (Table 2). This relationship is closely linked to the porosity reduction of higher cement content mortars and their consequent higher C3A content (Byfors, 1990; Rasheeduzzafar et al., 1990).

Considering the porosity reduction in higher cement content mortars, the results show a porosity decrease from mortar 1:2:9 to mortar 1:3 which can be seen with the decrease of total porosity values from $23.7 \%$ to $18.2 \%$, respectively (Table 2). This aspect reflects on chloride profiles shown in Figures 5 and 6 , as higher open porosity makes the chloride transport easier (Tuutti, 1982; Jaegermann, 1990). Considering the C3A content, higher cement content means higher C3A content available to fix chlorides in the cementitious matrix (Byfors, 1990; Rasheeduzzafar et al., 
1990). This stronger binding ability reduces the amount of free chlorides, which are the ones able to effectively be transported. Thus, profiles with less chloride concentrations are observed.

The differences on chloride transport in mortar influence its transport into concrete. Figures 5 and 6 show that there is a good harmony between the part of chloride profile in the mortar region and that in the concrete region. It means that if fewer chloride ions reach the interface between both materials, even fewer ions are transported into concrete. The analysis of Figures 5 and 6 shows the positive effect of the rendering mortar in reducing the chloride content inside the concrete. However, this effect depends on mortar characteristics, such as its porosity and its chloride binding ability. This protective effect almost cannot be observed for mortar 1:2:9. However, it increases for mortars 1:1:6 and $1: 3$ and it is more pronounced for $4 \mathrm{~cm}$ of rendering mortar thickness.

Another way to analyse the influence of the mortar characteristics on chloride profiles in the concrete region is through the ratio between the cumulative total chloride concentration in the mortar layer (area under the profile in the mortar layer) and the cumulative total chloride concentration in the concrete layer (area under the profile in the concrete layer), which is shown in Figure 8. A nonlinear relationship is observed in this figure. It shows that more chlorides are transported from mortar to concrete as more chlorides are accumulated in the mortar layer.

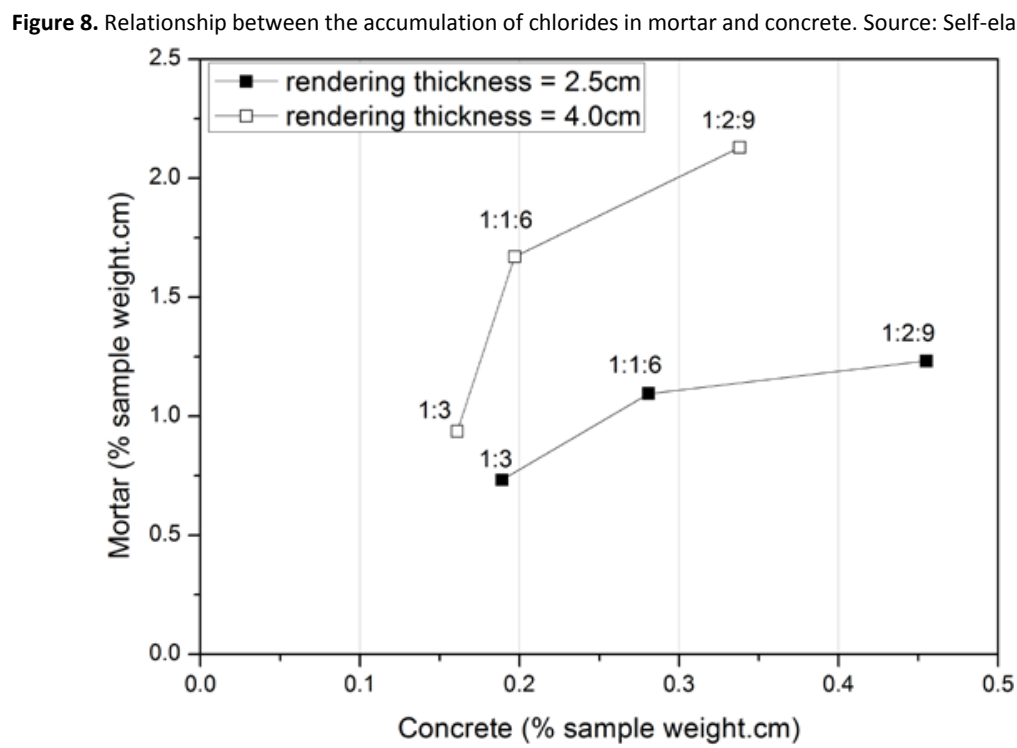

This behaviour is explained by the fact that more porous mortars contribute to a rapid initial chloride transport into their layer and therefore this increases the chloride concentration on the concrete surface, which contributes to an increase in mass transport into concrete. Table 3 clarifies this point by presenting the results of the surface chloride concentration in concrete layer (Cs) and total chlorides accumulated in this region. The first one was obtained from the fittings presented in section 4.2, which show, at the depth zero, values of the surface chloride concentration in concrete layer. The second one was obtained from the area under the profiles shown in Figures 5, 6 and 7 in concrete layer.

\begin{tabular}{|c|c|c|c|}
\hline \multicolumn{2}{|c|}{ Specimens characteristics } & \multirow{2}{*}{$\begin{array}{l}\text { Cs concrete } \\
\text { (\% sample weight) }\end{array}$} & \multirow{2}{*}{$\begin{array}{l}\text { Area under profile in the concrete region } \\
\text { (\% sample weight.cm) }\end{array}$} \\
\hline $\begin{array}{l}\text { Rendering } \\
\text { thickness }(\mathrm{cm})\end{array}$ & Mortar & & \\
\hline 0 & --- & 0.38 & 0.47 \\
\hline \multirow[t]{3}{*}{2.5} & $1: 2: 9$ & 0.34 & 0.45 \\
\hline & 1:1:6 & 0.27 & 0.28 \\
\hline & $1: 3$ & 0.12 & 0.19 \\
\hline 4 & $1: 2: 9$ & 0.31 & 0.34 \\
\hline
\end{tabular}




$\begin{array}{lll}1: 1: 6 & 0.19 & 0.20 \\ 1: 3 & 0.15 & 0.16\end{array}$

By Table 3, it can be observed that for 2.5 rendering mortar thickness Cs decreases $10 \%, 29 \%$ and $68 \%$ for mortars 1:2:9, 1:1:6 and 1:3, respectively, when compared to reference concrete. For $4 \mathrm{~cm}$ rendering mortar thickness these values reach $18 \%, 50 \%$ and $60 \%$, respectively. This behaviour of Cs reflects on chlorides accumulated in the concrete region, with reductions in total chlorides accumulated in this region that range from $4 \%$ to $66 \%$, depending on mortar characteristics and rendering thicknesses.

\section{Influence of rendering mortar thickness}

To evaluate the influence of rendering mortar thickness on chloride transport into concrete, fittings were performed based on the solution of Fick's 2nd law (Equation 1). For this purpose, the profiles in the concrete layer were rescaled according to the procedure described by Andrade et al. (1997b), as shown in Figure 9. This procedure takes into account only the profiles region corresponding to the concrete zone and considers a new "zero" depth reference that is the interface between mortar and concrete. It is worth remembering that, in this case, the prevalence of chloride transport by diffusion in concrete layer was accepted, as discussed in section 3.

These fittings represent an approximation to real conditions, as commented in section 1 . However, as the objective of this section is to analyse the influence of mortar thickness on chloride penetration into concrete and that determination coefficients showed significant values, this procedure was adopted in the present work.

Figure 9. Rescaling of chloride profiles. Source: self-elaboration.

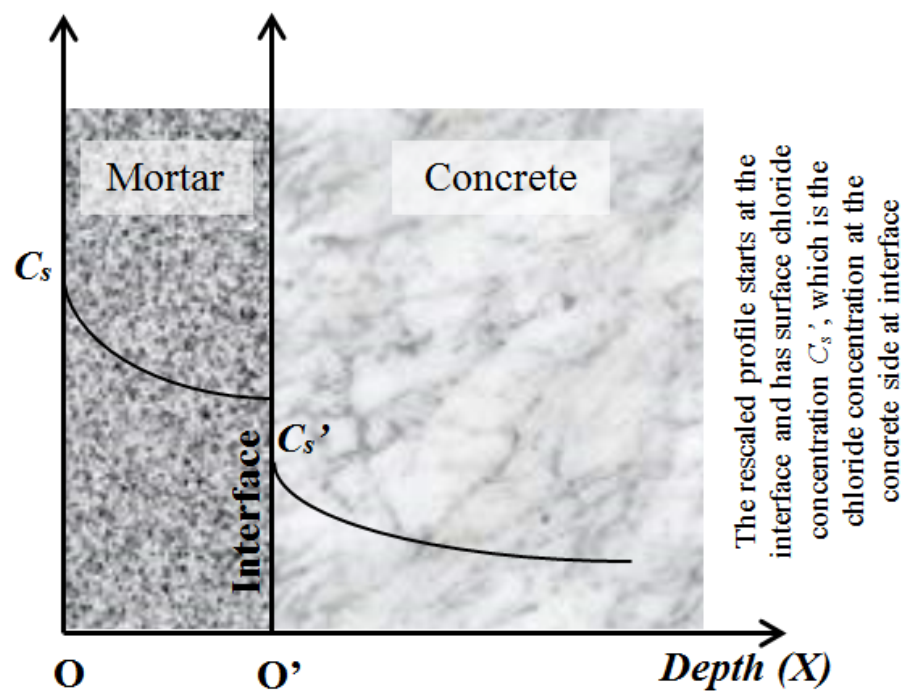


The results of these fittings are presented in Figure 10 and show that the rendering thickness is a factor that influences the chloride transport into concrete. However, this influence is clearer for less porous mortars, indicating that this beneficial effect should only be considered until a certain porosity level of mortars. In regards to this study, it should be considered specifically for mortars 1:3 and 1:1:6.

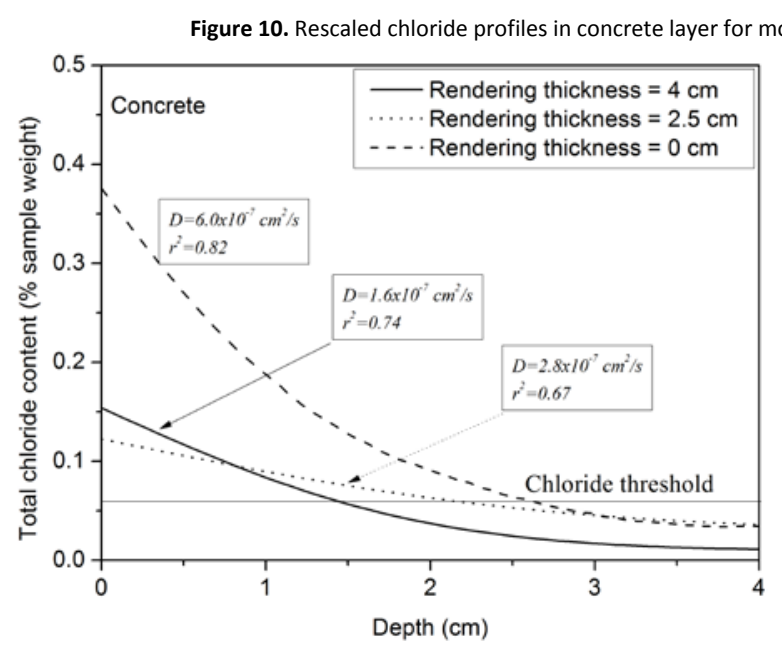

A

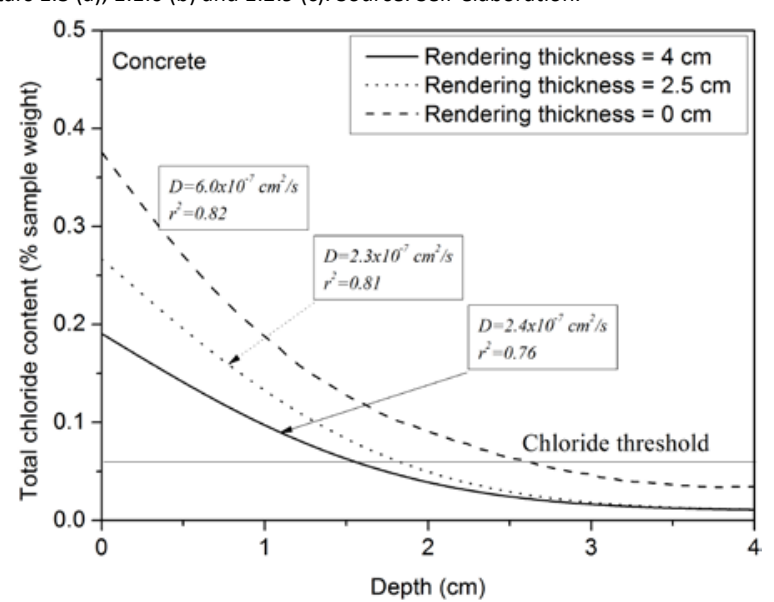

B

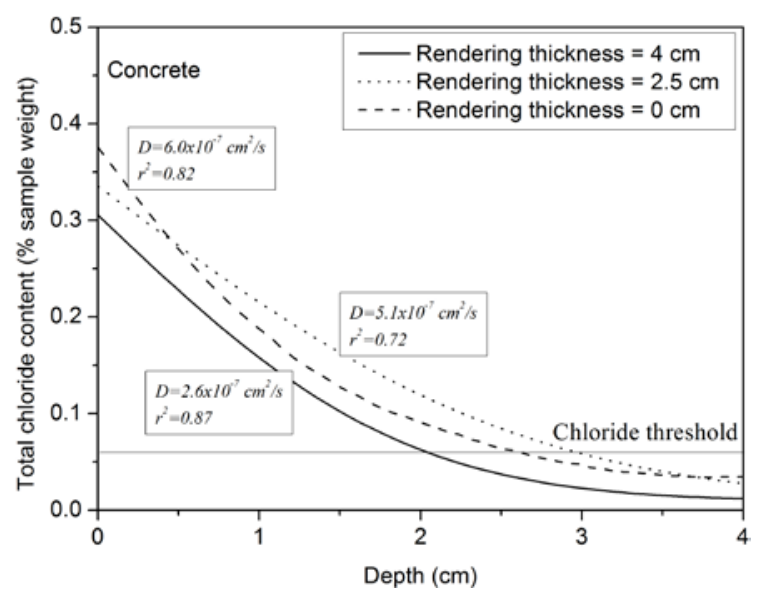

C

Considering that different chloride contents reach the interface between mortar and concrete, diffusion coefficients presented in Figure 10 cannot be directly compared, as they represent different exposure condition of concretes. However, a general slight decrease tendency of this parameter can be observed as rendering thickness increases, as a consequence of having less chlorides available to be transported into concrete.

Taking into account the chloride threshold, which in this case corresponds to $0.065 \%$ of concrete weight $(0.4 \%$ of cement weight (Glass and Buenfeld, 1997), Table 4 shows the reduction of the depth at which this threshold is reached in concrete in proportion as the thickness of rendering mortar layer increases.

Comparing the results shown in Table 4 and the curves shown in Figure 10, it can be said that 2.5 $\mathrm{cm}$ of mortar 1:1:6 is equivalent to $0.80 \mathrm{~cm}$ of concrete, while the same thickness of mortar $1: 3$ is equivalent to $0.60 \mathrm{~cm}$. This lower relation of equivalence for the mortar 1:3 is a consequence of the fitting process, which generated a raised end of the curve for a profile already with lower chloride contents. In regards to $4 \mathrm{~cm}$ rendering thickness, the equivalent concrete thickness corresponds to $1.10 \mathrm{~cm}$ and $1.25 \mathrm{~cm}$, respectively. The rendering mortar 1:2:9 presented little protection 
capacity, with close profiles for rendering thicknesses of 0 and $2.5 \mathrm{~cm}$ and equivalent thickness of concrete of only 0.55 $\mathrm{cm}$ for $4 \mathrm{~cm}$ rendering thickness.

Table 4. Relationship between rendering thickness and the depth at which chloride threshold is reached. Source: Self-elaboration.

\begin{tabular}{cll}
\hline \multicolumn{2}{l}{ Specimens characteristics } & \multicolumn{2}{c}{ chloride threshold depth $(\mathrm{cm})$} \\
\cline { 1 - 2 } Rendering thickness $(\mathrm{cm})$ & Mortar & \\
\hline 0 & -- & 2.65 \\
\hline 2.5 & $1: 2: 9$ & 2.90 \\
& $1: 1: 6$ & 1.85 \\
& $1: 3$ & 2.05 \\
\hline 4 & $1: 2: 9$ & 2.10 \\
& $1: 1: 6$ & 1.55 \\
& $1: 3$ & 1.4 \\
\hline
\end{tabular}

\section{Resistance effect at the interface between mortar and concrete}

The chloride profiles of layered specimens presented in Figures 5 and 6, indicate that there is an accumulation of chlorides in the region immediately before the interface, followed by a reduction in chloride content in the region of the concrete. This reduction in chloride content, when crossing from mortar layer to concrete layer, is seen as a beneficial effect of resistance against chloride penetration into concrete layer imposed by the materials characteristics.

This effect is related to differences in mass transport ability of materials (Andrade et al., 1997a). The porosity difference between the rendering mortar and concrete is a factor that contributes to this accumulation of ions at the interface. Thus, it is expected that the lower the porosity of the mortars is and closer to the porosity of the concrete, the lower the resistance effect will be.

Fitting the equations that represent chloride transport in mortar and concrete layers (see Equations 2 - 4) to the obtained profiles (Figures $5-6$ ), it is possible to obtain the curves shown in Figure 11. The diffusion coefficients for the concrete zone were similar to those obtained by rescaling profiles procedure (section 4.2). The diffusion coefficients obtained for mortar zone were significantly higher, as they represent a more porous material, where chlorides are easily transported. No clear tendency can be observed when comparing this parameter to the different mortars. The different Cs values and the accumulation of chlorides close to the interface contributes to explain this behaviour.

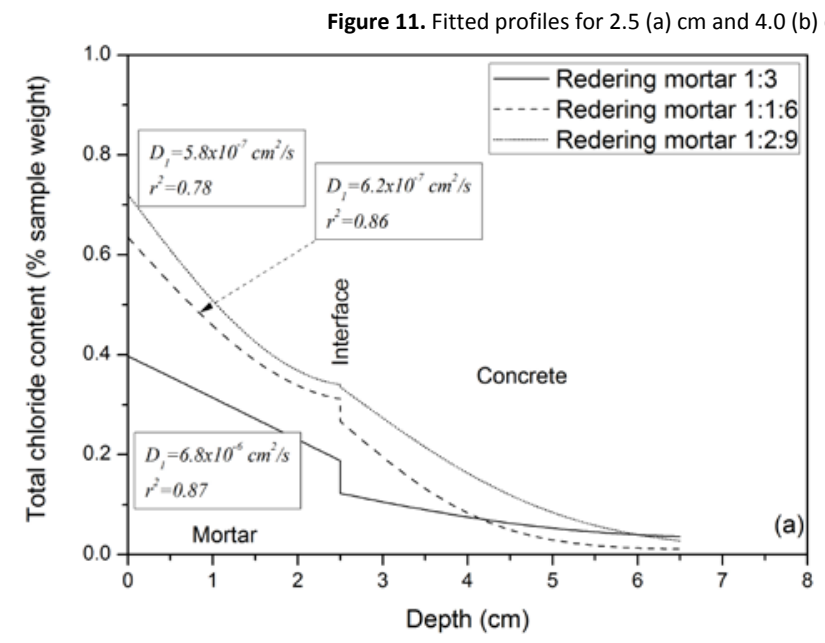

A

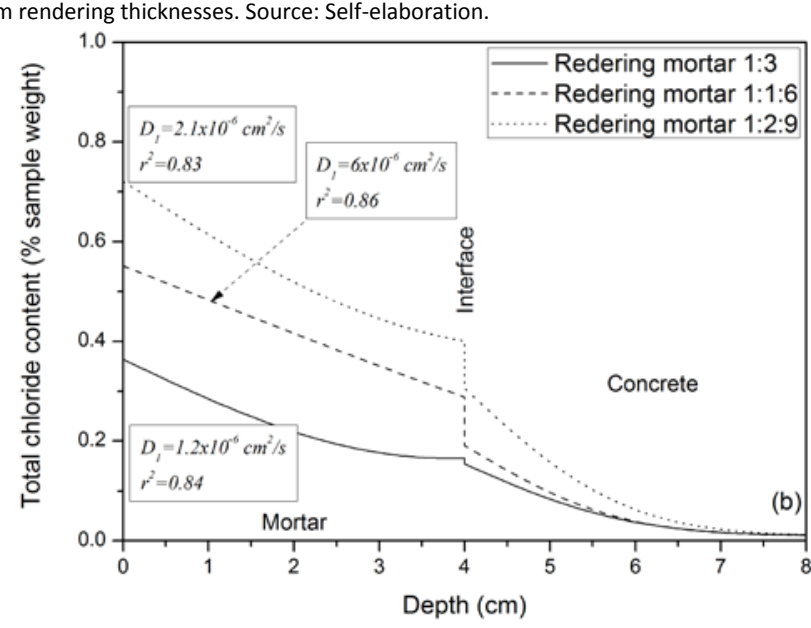

B 
According to Figure 11 and Table 5, the value of $R$, which represents the resistance effect, shows a slight decrease with mortar porosity increase for $2.5 \mathrm{~cm}$ rendering thickness. This behaviour is a priori against the initial expectations.

Table 5. Resistance effect at the interface mortar-concrete measured by R parameter. Source: Self-elaboration.
\begin{tabular}{lll}
\hline Specimens characteristics & $R=C_{1} / C_{2}$ \\
\hline Rendering thickness $(\mathrm{cm})$ & Mortar & 1.01 \\
\hline 2.5 & $1: 2: 9$ & 1.17 \\
& $1: 1: 6$ & 1.53 \\
\hline 4 & $1: 3$ & 1.41 \\
& $1: 2: 9$ & 1.50 \\
& $1: 1: 6$ & 1.08 \\
\hline
\end{tabular}

Analysing the layered specimens with $2.5 \mathrm{~cm}$ rendering thickness in more details, it can be seen that the profiles related to higher porosity mortars show an accumulation of chlorides in the region immediately before the interface region in a longer stretch. This accumulation comes from the early arrival of chloride ions in the region. The longer the accumulation in the region prior to the interface, the extended the period in which the chlorides from the mortar region accumulated in this region and were consequently transferred to the concrete. This increase in the transfer period allows the reduction of the difference of concentrations between mortar and concrete at the interface and thus provides the decrease in the $\mathrm{R}$ value.

For the rendering thickness of $4 \mathrm{~cm}$, this accumulation is not so clear, indicating that the effect of early accumulation in the region immediately before the interface was probably not significant and this behaviour is reflected in $R$ values . As a result, $R$ values should not be directly compared, because different transport situations would be compared since, for higher porosity mortars and specimens with $2.5 \mathrm{~cm}$ rendering thickness, chloride transport from mortar to concrete took place at higher levels and earlier than for the lower porosity mortars and specimens with $4 \mathrm{~cm}$ rendering thickness. As a consequence, $\mathrm{R}$ value is not constant, but decreases depending on the time of testing or observation. The values observed here represent those related to the end of the tests.

Conclusions

The performed experiments indicate that the rendering mortars act positively in relation to the delay of chloride penetration into concrete. However, this behaviour depends on materials characteristics. With regards to the mortar characteristics, those with higher cement content and less porosity have a more significant contribution on delaying chloride penetration into concrete. Poor mortars should have their protective effect neglected, due to their minimal contribution.

Furthermore, there is a resistance effect in chloride transport from mortar to concrete. This effect is present in all analysed experimental conditions and arises from the differences in the mass transport ability of the studied materials. However, in regards to the resistance effect, the analysis of the R parameter must be done carefully, taking into account the early chloride accumulation that takes place before the interface mortar-concrete for longer test periods.

These aspects taken simultaneously show that, although mortars usually have higher porosity than concrete, they can contribute to protect reinforced concrete structures against chloride penetration and this additional protection can be considered as an equivalent additional concrete thickness, which for this work remained between 0.6 and $1.25 \mathrm{~cm}$.

The authors thank the team of Materials and Structures Laboratory of the Federal University of Paraíba and the Federal Institute of Education, Science and Technology of Paraíba for helping on this research project activities. The authors also thank the Brazilian Council of Scientific and Technological Improvement (CNPq) and CAPES (Brazilian Government Agency for the Improvement of Graduated Professionals) for supporting this research. 
ABNT. (1987). NBR 9778 - Hardened cement mortar and concrete - Determination of water absorption by immersion. ABNT.

ABNT. (1995). NBR 9779 - Hardened mortar and concrete - Determination of water absorption by capillarity - Method of test. ABNT.

Aïtcin, P. C. (2000). High performance concrete. São Paulo: Pini.

Al-Khaja, W. A. (1997). Influence of temperature, cement type and level of concrete consolidation on chloride ingress in conventional and highstrength concretes. Construction and Building Materials, 11(1), 9-13. https://doi.org/10.1016/S0950-0618(97)00004-4

Andrade, C., \& Castellote, M. (2002). RILEM TC 178-TMC: “Testing and modelling chloride penetration in concrete" Analysis of total chloride content in concrete. Materials and Structures, 35(253), 583-585. https://doi.org/10.1007/BF02483129

Andrade, C., Díez, J. M., \& Alonso, C. (1997a). Modelling of skin effects on diffusion process in concrete. Proceedings of the RILEM International Workshop on Chloride Penetration into Concrete (182-194). Paris.

Andrade, C., Díez, J. M., \& Alonso, C. (1997b). Mathematical Modeling of a Concrete Surface "Skin Effect" on Diffusion in Chloride Contaminated Media. Advanced Cement Based Materials, 6(2), 39-44. https://doi.org/10.1016/S1065-7355(97)00002-3

Bakker, R. F. M. (1988). Initiation period in Corrosion of steel in concrete. (22-55) In P. SchiessI (Ed.). Chapman \& Hall., London.

Byfors, K. (1990). Chloride - Initiated Reinforcement Corrosion: Chloride Binding. Stockholm: CBI.

Castro, P., De Rincon, O., \& Pazini, E. (2001). Interpretation of chloride profiles from concrete exposed to tropical marine environments. Cement and Concrete Research, 31(4), 529-537. https://doi.org/10.1016/S0008-8846(01)00453-7

Climent, M. A., de Vera, G., López, J. F., Viqueira, E., \& Andrade, C. (2002). A test method for measuring chloride diffusion coefficients through nonsaturated concrete. Cement and Concrete Research, 32(7), 1113-1123. https://doi.org/10.1016/S0008-8846(02)00750-0

Crank, J. (1975). The Mathematics of Diffusion (2nd ed.). Oxford: Oxford University Press.

De Vera, G., Climent, M. A., Viqueira, E., Antón, C., \& Andrade, C. (2007). A test method for measuring chloride diffusion coefficients through partially saturated concrete. Part II: The instantaneous plane source diffusion case with chloride binding consideration. Cement and Concrete Research, 37(5), 714-724. https://doi.org/10.1016/j.cemconres.2007.01.008

Glass, G. K., Buenfeld, N. R. (1997). Chloride threshold levels for corrosion induced deterioration of steel in concrete. Proceedings of the International RILEM workshop on chloride penetration into concrete (429-440). Paris.

Guimarães, A. T. C., Helene, P. R. L. (2005). Chloride diffusion and the influence of the saturation degree of the concrete. Proceedings of the Third RILEM workshop on testing and modelling the chloride ingress into concrete (237-256). Madrid.

Guimarães, A. T. C., Climent, M. A., Vera, G. De, Vicente, F. J., Rodrigues, F. T., \& Andrade, C. (2011). Determination of chloride diffusivity through partially saturated Portland cement concrete by a simplified procedure. Construction and Building Materials, 25(2), 785-790. https://doi.org/10.1016/j.conbuildmat.2010.07.005

Jaegermann, C. (1990). Effect of water-cement ratio and curing on chloride penetration into concrete exposed to Mediterranean Sea climate. ACI Materials Journal, 87(4), 333-339. https://doi.org/10.14359/2039

Jones, M. R., McCarthy, M. J. \& Dhir, R. K. (1994). Chloride ingress and reinforcement corrosion in carbonated and sulphated concrete. In: Swamy, R. N. (Ed.). Proceedings of the International conference on corrosion and corrosion protection of steel in concrete (365-376). Sheffield: Sheffield Academic Press.

Kreijger P C. (1984). The skin of concrete: composition and properties. Materials and Structures, 17 (4), $275-283$. https://doi.org/10.1007/BF02479083

Kröpp, J., Hilsdorf, H., Grube, H., Andrade, C., \& Nilsson, L.O. (1995). Transport mechanisms and definitions. In: Kröpp, J., Hilsdorf, H. K. (Ed.). Performance criteria for concrete durability (report 12 - RILEM) (4-14). London: E \& FN Spon

Lindvall, A. (2007). Chloride ingress data from field and laboratory exposure - Influence of salinity and temperature. Cement and Concrete Composites, 29(2), 88-93. https://doi.org/10.1016/j.cemconcomp.2006.08.004

Malheiro, R. (2008). Influence of rendering mortar on chloride transport into reinforced concrete structures in urban environment. Federal University of Paraíba, Brazil.

Malheiro, R., Camões, A., Ferreira, R. M., Meira, G., Amorim, T., \& Reis, R. (2014). Carbonation Front Progress in Mortars Containing Fly Ash Considering the Presence of Chloride lons. Key Engineering Materials, 634, 214-221. https://doi.org/10.4028/www.scientific.net/KEM.634.214

Malheiro, R. M. de C., Meira, G. R., \& Lima, M. S. de. (2014). Influência da camada do revestimento de argamassa na penetração de cloretos em estruturas de concreto. Ambiente Construído, 14(1), 41-55. https://doi.org/10.1590/S1678-86212014000100005

Malheiro, R., Camões, A., Ferreira, R.M., Meira, G., Amorim, T., \& Reis, R. (2015). Carbonation front progress in mortars containing fly ash considering the presence of chloride ions. Key Engineering Materials, 634, 214-221. https://doi.org/10.4028/www.scientific.net/KEM.634.214 
Mangat, P. S., \& Gurusamy, K. (1987). Chloride diffusion in steel fibre reinforced concrete containing PFA. Cement and Concrete Research, 17(4), 640-650. https://doi.org/10.1016/0008-8846(87)90137-2

Mangat, P. S., \& Molloy, B. T. (1994). Prediction of long term chloride concentration in concrete. Materials and Structures, $27(6)$, 338-346. https://doi.org/10.1007/BF02473426

Martín-Pérez, B. (1999). Service life modelling of R. C. highway structures exposed to chlorides. Phd Thesis. University of Toronto, Canada.

Meijers, S. J. H. (2003). Computacional modelling of chloride ingress in concrete. Phd Thesis. Delft University, Netherlands.

Meira, G., Andrade, C., Alonso, C. \& Borba Jr, J. C. (2007a). Chloride penetration into concrete structures in marine atmosphere zone - influence of environmental characteristics. Proceedings of the International RILEM workshop on integral service life modelling of concrete structures (4754). Guimarães: RILEM.

Meira, G. R., Andrade, C., Padaratz, I. J., Alonso, C., \& Borba, J. C. (2007b). Chloride penetration into concrete structures in the marine atmosphere zone - Relationship between deposition of chlorides on the wet candle and chlorides accumulated into concrete. Cement and Concrete Composites, 29(9), 667-676. https://doi.org/10.1016/j.cemconcomp.2007.05.009

Nielsen, E. P., \& Geiker, M. R. (2003). Chloride diffusion in partially saturated cementitious material. Cement and Concrete Research, 33(1), 133-138. https://doi.org/10.1016/S0008-8846(02)00939-0

Nilsson, L. O., Tang, L. (1996). Transport mechanisms in porous materials - an introduction to their basic laws and correlations. Proceedings of the International Congress on Modelling of Microstructure and its Potential for Studying Transport Properties and Durability (289-311). SaintRémy-lés-Chevreuse: Kluwer Academic Press.

Page, C. L., Short, N. R., \& El Tarras, A. (1981). Diffusion of chloride ions in hardened cement pastes. Cement and Concrete Research, 11(3), 395-406. https://doi.org/10.1016/0008-8846(81)90111-3

Rasheeduzzafar, F.H., Al-Saadoun, S. S., Al-Gahtani, A. S., \& Dakhil, F. H. (1990). Effect of tricalcium aluminate content of cement on corrosion of reinforcing steel in concrete. Cement and Concrete Research, 20(5), 723-738. https://doi.org/10.1016/0008-8846(90)90006-J

Tuutti, Kyösti. (1982). Corrosion of steel in concrete. Stockholm: Swedish Cement and Concrete Research Institute.

Vera, R.; Villarroel, M.; Delgado, D.; Carvajal, A. M.; De Barbieri, F.; Troconis, O. (2009). DURACON: Influencia de la Acción del Medio Ambiente en la Resultados de Chile después de 5 años de Exposición. Revista de La Construcción, 8(1), 13-23. 